\title{
Androgen Deprivation Therapy for Prostate Cancer
}

\author{
Stanislav Ziaran \\ University Hospital in Bratislava, Urology Clinic, Comennius University \\ Slovakia
}

\section{Introduction}

Since 1941, when Huggins and Hodges proved the favourable effect of surgical castration and oestrogen administration on the progression of metastatic prostate cancer (PCa) $(1,2)$, androgen deprivation therapy (ADT) became the mainstay of management of advanced PCa till now. They demonstrated for the first time the responsiveness of $\mathrm{PCa}$ to androgen deprivation.

ADT effectively palliates the symptoms of advanced disease, significantly reduces tumor growth, but there is no conclusive evidence at present that it prolongs survival. Moreover, significant amount of data report that ADT is associated with several adverse effects. The most prominent include: loss of bone mineral density (BMD), which leads into increased fracture risk (3), induction of insulin resistance (4), unfavorable changes in serum lipid profile (5), changes in body composition (6) which can lead into increased cardiovascular morbidity (7) and changes in cognitive functions (8).

The aim of ADT is to cause severe hypogonadism, and adverse effects of ADT clearly demonstrate the essential and pluripotent role of male's most important androgen testosterone (TST).

\section{Testosterone: A basal overview of biosynthesis, metabolism and its action}

In the human male, the main circulating androgen is testosterone (TST). More than $95 \%$ of circulating TST is secreted by the testis (Leydig cells) which produce aproximately 6-7 $\mathrm{mg}$ of TST daily (9). The rest is secreted by the adrenal cortex, and very small quantities (especially pregnan derivatives) are formed by the cells of the brain (10).

Physiologic TST level in a male is 3-8 $\mathrm{ng} / \mathrm{ml}$. The source for the synthesis of steroids is cholesterol. This substrate may be synthetized de novo from acetate but it may be also taken up from plasma lipoproteins. Cleavage of the side chain of cholesterol in the mitochondria and the formation of pregnenolone (biologically inactive) is the start of steroidogenic cascade. Pregnenolone is further converted into various steroids by enzymes (cytochromes $\mathrm{P} 450)$ in the endoplasmatic reticulum.

TST secretion is regulated by the hypothalamic-pituitary-gonadal axis. The hypothalamic luteinising hormone-releasing hormone (LHRH) stimulates the anterior pituitary gland to release luteinising hormone $(\mathrm{LH})$ and follicle-stimulating hormone (FSH). The main regulator of Leydig cell function is $\mathrm{LH}$, acting through the LH receptor (LHr) in Leydig cells. 
LH and FSH are required for the development and maintance of testicular functions. The natural ligand for the LHr is LH, but also human choriogonatropin (hCG) can equally well activate the LHr. Activated LHr stimulate adenylyl cyclase via GTP binding proteins and this results in increased production of cyclic AMP (cAMP). cAMP increases steroid production (11).

The total concentration of steroids in target tissues (central and peripheral nervous system, bone, muscle, adipose tissue, haematopoetic system and myocardium) and body fluids is dependent on the presence of binding proteins (sex hormone binding globulin, SHBG, albumin). Binding proteins represent a storage form of circulating steroids, which bind $98 \%$ of circulating TST. The rest- $\%$ is "free testosterone" (fTST), which is biologically active. Homeostasis is achieved by "closed" steroid feedback inhibition mechanism, where the plasmatic level of steroids affects the secretion of LH from adenohypophysis.

The effect of TST on target tissues is modulated by metabolic pathways.

1. Aromatisation of TST gives rise to $17 \mathrm{~b}$ - estradiol. When the target cell is estrogendependent, the aromatase activity in target cells and supply of androgen substrate (TST) are of major importance for determining the rate of synthesis of estrogens. Aromatase cytochrome P450 enzyme is expressed in many tissues including placenta, ovary, testis, fat tissue, liver, brain, hair follicles.

2. Reduction of TST into 5-alfa-dihydrotestosterone (DHT) is achieved by 5a-reductase. This active form of TST ( 5 to 10 times more biologically effective) can fully activate the androgen receptor (AR) (12). There are 3 isoforms of 5a-reductase. Isoform 2 is clinically more important because its deficiency is associated with distinct clinical manifestations (13). Isoform 2 predominates in cells of the prostate and external genitalia, while isoform 1 predominates in the cells of the skin (except genitals), and in liver cells in small amounts. However, in prostate cancer cells, overexpression of isoform 1 is a common finding, thus increasing its clinical significance (14). In the total deficiency of isoform 2 (autosomal recessive) there is a serious alteration of the development of sex organs in utero (male pseudohermafroditism). Many mutations of the gene encoding isoform 2 are known and can result into a number of different clinical manifestations. Signs of its deficiency are small phallus, severe hypospadias, scrotum bifidum, residual prostate utriculus (15). The newly discovered isoform 3 may play an important role in the development of hormone-refractory prostate cancer (HRCaP) as its overexpression is found in the HRCaP cells (16).

In addition to these metabolic pathways, the level of DHT in target tissues is affected by other enzymes (hydroxysteroid dehydrogenases), which "fine-tune" the effect of androgens in the target tissues (17). Owing to these local conversions the peripheral plasma concentration of androgens are only a rough indicator for their biological activities (12).

The mechanism of action of androgens can be divided into genomic and non-genomic effect (12). Non - genomic effects of androgens include mechanisms affecting the flow of calcium in the cells and the effect on phosphorylation cascade of Map-kinase $(18,19)$, or membrane effects (20). Genomic effects are mediated by activation of androgen receptor (AR). AR acts as a transcription factor activated by its ligand (TST). By androgen binding, AR is translocated from the cytoplasm to the nucleus where it binds to its DNA domain and interacts as a homodimer with specific DNA sequences that are referred as androgen responsive elements (ARES) (21). Its binding to DNA leads into interactions with transcription factors (22) and other co-factor proteins (21). This results into the "up" or "down" regulation of transcription of target genes (23). 
Androgen metabolites are excreted as free steroids or bound (conjugated). Conjugated steroids are bound to glucuronide or sulfate group. Androgens are mostly degraded in the liver (glucuronate, sulphates), but the prostate the skin also contribute significantly to the metabolism of androgens. All the steroid - metabolising enzymes constitute a network for transforming androgens into secretion products (conjugated, unconjugated) that finally leave the body via the urine or the skin. The flux though this network is great, because the half-life of TST in men is only 12 minutes (12).

\section{Androgens and bone metabolism}

Growth and resorption of bone tissue are mediated by osteoblasts and osteoclasts. Both types of cells exert mutual influence on each other and equilibrium between the activity of both cell lines maintains net bone mass during constant renewal and turnover. Decreased osteoblast activity and increased activity of osteoclasts leads into loss of bone mass. AR have been located on normal human osteoblasts (24) and both aromatizable and nonaromatizable androgens can stimulate of human osteoblasts proliferation in vitro (25).

Bone deformation strain represents a stimulus for osteoblastic activity. Androgens modify the effects induced by the mechanoreception of human osteoblastic cells by affecting adhesion molecule expression, i.e. fibronectin and the fibronectin receptor. These substances facilitate the adhesion of bone cells to the extracellular matrix, which represents a crucial requirement for osteoblastic development and function (26). In addition, the secretion of osteoprotegerin (OPG), which is unaffected by mechanical strain alone, is doubled when this stimulus occurs in the presence of androgens. OPG is a decoy receptor for RANKL (receptor activator of nuclear factor-kappaB ligand). RANKL is secreted by osteoblasts, it induces osteoclastogenesis stimulates osteoclast differentiation (27). Thus, OPG inhibits bone resoptive effect induced by RANKL (26). Accordingly, TST levels directly correlate with OPG concentrations in healthy men (28).

Parathyroid hormone (PTH) induces osteoclast formation a differentiation. Androgens have direct inhibiting effect on this process via osteoclasts, which express AR and these cells are also blocked form PTH effects by androgens when no conversion to estrogens occurs (29).

Androgens decrease the number of bone remodeling cycles by modifying the genesis of osteoclasts and osteoblasts from their respective progenitor cells. In addition, androgens also exert effects on the lifespan of mature bone cells: they exert pro apoptotic effects on osteoclasts and anti-apoptotic effects on osteoblasts and osteocytes. TST also modulates effects induced by other hormones and cytokines involved in bone metabolism (30).

Osteoblast activity is reflected by concentration of procollagen type 1 (carboxy-terminal: P1CP or amino-terminal: P1NP) and other non collagenous proteins secreted by osteoblasts, eg. osteocalcin and bone specific alkaline phosphatase (BSAP). Also OPG as a decoy receptor for RANKL, can serve as marker of osteoblast activity. Bone resorption, hence osteoclast activity, therefore, can be estimated by urinary excretion of degradation products of type I collagen, such as deoxypyridinoline (DPD) and collagen type I cross- linked Ntelopeptide (NTX) (31).

An independent role of androgens in protecting bone mass, both by promoting bone formation and attenuating bone resorption has been demonstrated in humans. Nevertheless, the role of its metabolite estradiol is pivotal in bone metabolism (30).

Aromatization of TST to estradiol is a pivotal event concerning effects of sex steroids on bone metabolism. Estrogen receptors (ER) have been localized in human osteoblasts (32), 
osteoclasts (33), and osteocytes (34). Human males with mutations of ER or aromatase genes do not achieve normal bone density, despite normal or increased levels of serum TST (35).

\section{Androgen deprivation therapy (ADT) and its side effects}

ADT is increasingly attained through the use of luteinizing hormone-releasing hormone (LHRH) agonists, which down-regulate anterior pituitary receptors and lead to therapeutic hypogonadism, or directly by inhibiting pituary receptors by LHRH antagonists. The standard castration level is $<50 \mathrm{ng} / \mathrm{dL}$. Prostate cells are physiologically dependent on androgens which stimulate its growth, function and proferation. TST, although not tumorigenic, is essential for the growth and perpetuation of tumor cells (36).

Prostate cancer (PCa) displays a range of clinical behavior, from slow-growing tumors of no clinical significance to aggressively metastatic and lethal disease. Most PCa cases diagnosed with present diagnostic techniques fall into the moderately differentiated group (grade 2, Gleason 6), of which the cancer-specific $10-15$-year mortality is $18-30 \%$. This is even lower in the group of PCa diagnosed with grade 1 and 2 or Gleason 4-6, and there are subgroups of patients who are not at risk of dying from PCa even within 15years. Overall mortality is then determined by comorbidity (37). While both short- and long-term ADT are effective for treating $\mathrm{PCa}$, it can often have significant side-effects. It is important that these complications are recognized and managed appropriately so that adverse effects on the patient's quality of life (QoL) are minimized. There has been an increase in the use of ADT at all stages of PCa in recent years. The extensive use of ADT is raising concerns about adverse effects - loss of BMD being the most prominent.

\section{Bone loss and osteoporosis}

As shown above, androgens are important for maintenance of bone tissue. Although ADT is used in medical practice for more than 60 years, it's only few years that the clinicians became aware of serious and potentially catastrophic consequences resulting form longterm ADT.

Bone density is determined both by peak bone mass achieved during skeletal development and the subsequent amount of maintenance and resorption of bone tissue. Androgens affect both processes and thus are a pivotal determinant of bone mass in men.

\subsection{Osteoporosis}

Osteoporosis is defined as a systemic metabolic bone disease characterized by low bone mass density (BMD) and microarchitectural deterioration of bone tissue, with a consequent increase in bone fragility and susceptibility to fracture (38). Diagnosis of osteoporosis based on WHO definitions is developed for women originally (39). When based on male cutoffs, 12 million ( $3-6 \%)$ of men have osteoporosis and $8-13$ million (28 - 47\%) have osteopenia; when based on female cutoffs, 280,000 - 1 million (1 - 4\%) have osteoporosis and $4-9$ million (15-33\%) have osteopenia $(40,41)$. While this numbers may seem disturbing, it is believed that osteoporosis in men is substantially underdiagnosed and undertreated in the United States (42).

Female osteoporosis has been studied extensively and characterized due to its high prevalence (43) whereas male osteoporosis, especially that associated with ADT has gained focus only recently. 
In men, osteoporosis occurs later than in women (44), but the prevalence of osteopenia does not differ significantly between men and women aged more than 50 years. Conversely, the prevalence of osteoporosis in men is lower than in women (40). Even though it may be underestimated when standard female BMD parameters are considered suitable for normal mineralization in men (45). Men generally have a higher BMD than women at the same age (46). Accordingly, the prevalence of male osteoporosis is greater when male-specific ranges are used in men above fifties: ranging from $1 \%$ to $4 \%$ of elderly men when the diagnosis is based on female cut-off points vs. $3 \%$ to $6 \%$ when based on male cut-off points (40).

Men are estimated to lose bone mineral density (BMD) at a rate of up to $1 \%$ per year with advancing age $(47,48)$, and one in eight men over age 50 years will experience an osteoporosis-related fracture in their lifetime (49). Of all osteoporotic fractures, hip fractures contribute to the greatest morbidity as well as mortality, both of which are much greater in men than in women (50-52).

\subsection{Diagnosis of osteoporosis}

Current guidelines recommend assessment of bone mineral density (BMD) previous to ADT and yearly thereafter (53) with dual-energy x-ray absorptiometry (DXA) which is considered the standard method to measure BMD (54). International Society for Clinical Densitometry (ISCD) recommends that central skeleton sites (lumbar spine, total hip and femoral neck) are the most appropriate locations to asses BMD (55).

Diagnosis of osteoporosis can than be made according to WHO classification: if T- score is less than 2,5 of standard deviation. Values between (-) 1 and (-) 2.5 SD (standard deviation) is defined as osteopenia. $\mathrm{T}$ - score stands for the number of standard deviations (SD) from the density of young healthy individuals of the same sex (39).(Table 1)

To improve the identification of patients at highest risk of fracture, WHO has developed an algorithm to predict fractures - FRAX TM http:/ / www.shef.ac.uk/FRAX/

According to European Association of Urology (EAU) guidelines, a precise evaluation of BMD should be performed by dual X-ray absorptiometry before starting long-term ADT. An initial low BMD (T-score below 2.5, or below 1 if other risk factors are present) indicates a high risk of subsequent non-metastatic fracture, suggesting the need for early use of preventive bisphosphonate therapy (56).

\begin{tabular}{|c|c|}
\hline Clasiffication & T-score \\
\hline Normal & $>-1$ \\
\hline Osteopenia & $-1--2,5$ \\
\hline Osteoporosis & $<-2,5$ \\
\hline
\end{tabular}

Table 1.

\subsection{ADT, prostate cancer ( $\mathrm{PCa}$ ) and clinical aspects of bone disease}

At presence, significant amount of data report that ADT is associated with the loss of BMD in a time-dependent manner (57-59) which leads into increased fracture risk (60). Skeletal fractures negatively correlate with overall survival in men with PCa (61) and maintaining skeletal health is crucial for QoL and survival (62).

Treatment of complications of pathological fractures is complicated and expensive (63). Moreover, the typical feature of PCa is the ability to metastasize into bone in more than $80 \%$ of cases (64). Most bone lesions in PCa are osteoblastic in nature (65). However, studies 
show that osteoblastic lesions in PCa have excessive bone growth, but on the other hand also simultaneously increased osteolysis (66). The new bone formed by tumor stimulated osteoblast is weak and poorly mineralized and subsequent osteopenia leads into increased osteolysis - result to the creation of bone matrix with seriously compromised integrity. The risk of developing bone complications is therefore increased.

Treatment of PCa does not focus on skeletal complications that may arise from bone metastases. The main symptom of bone metastases is severe bone pain, which often requires strong narcotic therapy or palliative radiation therapy. Other complications include spinal cord compression and pathological fractures, which may require surgery. These skeletal complications have a negative effect on QoL (65).

Data from a double-blind, placebo-controlled studies show that approximately half of patients treated with ADT had one or more events associated with the skeleton. Most of these events required palliative radiotherapy, or were pathological fractures (67). Skeletal complications are also associated with significant financial expenditure. A recent analysis of the costs of health insurance in the U.S. since 1994 until 2002 revealed that the total cost to treat patient with PCa who had skeletal event were 20000 dollars higher than in patient who did not experience skeletal event (68).

Interestingly, it has been reported that hormone naive patients with advanced PCa have lower baseline BMD than healthy control, and relatively high prevalence of osteopenia and osteoporosis $(69,70)$. The largest study that investigated the association of BMD measures with PCa risk in older men enrolled was the Osteoporotic Fractures in Men Study (MrOS) (71).

MrOS was prospective study conducted on 4597 men with mean follow up 5.2 years, which evaluated the association of BMD and incidental PCa in a cohort of older men with no history of PCa. Unexpectedly, the authors found that higher total body BMD was significantly related to reduced risk for PCa. This result was "unexpected“ because authors presumed that the higher levels of androgens lead into higher prevalence of PCa, which positively correlates with BMD. Additionally, total body BMD was inversely associated with the development of high-grade, but not low-grade disease. A similar but weaker association was observed for total hip BMD with high-grade PCa. This study confirms the association, although still not elucidated, between low BMD and PCa.

\subsection{Treatment of ADT induced osteoporosis}

Lifestyle changes: Immobilization is an important cause of bone loss. Immobile patients lose bone mass more rapidly than mobile patients. Regular daily activities, overcoming gravity, walking, and exercise have a positive impact on bone density: it stimulates osteoblasts to produce new bone and inhibits osteoclasts, thereby decreasing resorption of bone. It also improves physical coordination (prevention of falls). Cessation of smoking, decreased alcohol consumption and normalization of body mass index (BMI) helps to maintain BMD (72).

Ca supplementation: The ideal is to ensure that the amount of calcium is taken in the normal diet. If the patient is unable to take the recommended amount of calcium in the diet (lactose intolerance, hyperlipoproteinemia, etc) it is recommended for calcium supplementation (1000mg - $1500 \mathrm{mg}$ daily) (72).

Vitamin D: Supplementation of vitamin D is recommended when its deficiency can be assumed or proven. The recommended daily dose is $400-800 \mathrm{IU}(10-20 \mathrm{mg})$. 
Bisphosphonates are one of the most potent inhibitors of bone resorption. The effect on the reduction of osteoporotic fractures has been demonstrated for treatment with alendronate, risedronate, ibandronate, etidronate and zoledronic acid. The effectiveness in reducing vertebral and nonvertebral fractures were confirmed by many studies $(73,74,75)$. The optimal regimen for zoledronic acid is unclear, because one study recommends treatment every 3 weeks (76), while another trial has produced similar results with an annual injection (77), and finally, another study reports that single infusion of zoledronic acid in patients receiving ADT reduces bone mineral loss and maintains BMD at least for 12 months during ADT (78).

One of the most important and serious adverse effect of bisphoshonate administration is jaw necrosis (79) The initial BMD could be used to guide the choice of regimen (80).Thus, a 3month injection might be given in osteoporotic patients, for whom a yearly injection is likely to provide insufficient protection (56).

Denosumab is a fully human monoclonal antibody against RANKL (see above). In the largest, well conducted study to date, denosumab was associated with $5.6 \%$ increase in the lumbar BMD versus $1 \%$ decrease in the placebo arm. There were also significant BMD increases at the total hip, femoral neck and distal third of the radius. $60 \mathrm{mg}$ was delivered subcutaneously every 6 months, was not associated with any significant toxicity, or delayed healing in vertebral fractures (81).

\section{Androgens and cognitive functions}

It is known that during certain developmental stages- especially during the first years of life, during adolescence, girls surpass in boys several verbal skills. Males excel after about the tenth year of life in non-verbal skills in adulthood, especially in spatial orientation and manipulation (82).

Evidence of a link between sex hormones and spatial abilities came from studies of individuals with Turner syndrome (XO karyotype, no gonadal hormones) or testicular feminization syndrome- (XY karyotype, the tissues are refractory to normal levels of TST). These patients have female external genitalia, they are raised as girls. In these patients verbal skills surpass their spatial abilities, which is a typical pattern of cognitive abilities of women (83).

Studies on men with idiopathic or acquired hypogonadotrophic hypogonadism confirm the importance of TST for spatial abilities. Short-term androgen supplementation did not restore spatial function, suggesting that low levels of sex hormones during the intrauterine and neonatal period have a lifelong impact (84).

Direct sex hormones manipulation supports the conclusion that androgens play an important role in cognition. The first experiments with direct hormonal manipulation can be traced back to 1941 when Simonson et al. (85) published their experiment using methyl TST that was administered to eunuchoids, castrated males, and elderly men. The result was an improved ability to perceive the flicker (critical flicker frequency), a measure of attention and alertness, as long as the androgen treatment lasted (86).

Androgen therapy was also administered to female to male transsexuals in high doses as a preparation before gender reassignment. Their spatial skills have significantly improved, while verbal skills declined considerably (87).

For ethical reasons, nowadays the manipulation of gonadal hormones is restricted to patients in clinical studies. Thus, the last such study was conducted in 1971. Klaiber et al. (88) studied the effect of infused TST on mental abilities in healthy male students. After a 4- 
hour infusion of TST or saline in the control group, performance of the control group (saline infusion) showed a significant decline in mental performance when compared to TST infused group.

\subsection{Potential mechanisms of action}

TST may impact cognition through several mechanisms. For example, activation of calcium channels in the brain occurs through rapid, nongenomic methods of action on G-proteincoupled, agonist sequestrable testosterone membrane receptors that initiate a transcription-independent signal pathway (89). TST also may impact cognitive performance directly through modulating neurotransmitters and stimulating neuronal connectivity, decreasing $\beta$-amyloid peptide production, and preventing N-methyl-Daspartate excitotoxicity (90) mechanisms implicated in cognitive disorders such as Alzheimer disease or dementia. Furthermore, some estrogen studies have highlighted several possible mechanisms through which this hormone can impact cognitive functioning (91). These include increasing cholinergic activity through its action of choline acetyltransferase, maintenance of dendritic spine density on CA1 pyramidal cells of the hippocampus and facilitating induction of long-term potentiation in the hippocampus, increasing serotonergic and cholinergic activity to maintain neural circuitry, altering lipoprotein, and decreasing risk of cerebral ischemia $(92,93)$.

\subsection{Cognitive functions and ADT}

Green et al were the first to systematically research the impact of androgen-ablation therapy on the cognitive functioning of men with PCa. Sixty-five men (mean age, 73 years) with advanced PCa were assigned randomly to 1 of 4 groups: leuprolide $(\mathrm{N}=19)$, goserelin $(\mathrm{N}=$ $20)$, cyproterone acetate $(\mathrm{N}=11)$, and monitoring without hormone treatment $(\mathrm{N}=15)$. All men participated in a battery of neuropsychological assessments at baseline (ie, 1 week before treatment) and then 6 months later. PSA and TST levels decreased significantly from baseline to 6 months for the 3 hormonally treated groups. Conflicting results emerged in the memory domain; men in the goserelin group surprisingly improved on 2 measures of memory (verbal [Wechsler Memory Scale-Revised] and visual [Rey-Osterrieth Complex Figure test]) but declined in another measure of verbal memory (Auditory Verbal Learning Test). The goserelin group also declined in a measure of executive functioning (Trails B). Of the 50 men on active treatments, 24 men showed a reliable decline (ie, >1 standard deviation) on at least 1 cognitive task, and 7 men showed a reliable change on 2 tasks, whereas the monitoring-only group showed no decline on any of the tasks (94).

Salminen et al researched the cognitive effects of ADT on 26 men who were diagnosed recently with PCa and who began ADT 2 months before radiotherapy. From baseline to 12 months, tests of visuomotor speed and of reaction time saw significant decreases. The decline in TST coincided with a decline in visuomotor processing (digit symbol), reaction time (10-choice reaction time), working memory speed (subtraction), sustained attention (vigilance), and recognition speed (recognition of letters) (95).

Jenkins et al assessed 32 men with standard neuropsychological assessments at 3 time intervals: at baseline, 3 months, and 9 months. The average age of these men was 67.5 years, and they used ADT for 3 to 5 months. Twenty-five healthy men, similar in age, served as the control group. Although there was no overall group effect, a greater percent of men in the ablation group reported a significant cognitive decline in 1 task $(47 \%)$ 
compared with the control group $(17 \%$; odds ratio, 4.412; $\mathrm{P}<.05)$ at the 3 -month time point. There were no significant differences between the groups at the 9-month time point. On specific domain analysis, the tasks most impacted at the 3 month time point were spatial memory and ability (96).

Joly et al compared physical and cognitive function in a cross-sectional study of 57 patients who were receiving ADT for nonmetastatic PCa and 51 healthy, age-matched controls. Thirty patients received ADT as adjuvant treatment after prostatectomy or radiotherapy, and 27 patients received ADT for increasing levels of PSA. The median duration on ablation therapy was 1.8 years (range, 0.4-7.4 years). To assess cognitive functioning, the researcher administered the Sensitivity Cognitive Screen and a self-reported assessment on cognitive deficits (the Functional Assessment of Cancer Treatment-Cognitive Scale [FACT-COG]). In contrast to other studies cited above, Joly and colleagues observed that, although men with nonmetastatic PCa who received ADT experienced more treatment-related symptoms, no differences in cognitive function on either the High Sensitivity Cognitive Screen or the FACT-COG. The authors suggested that the High Sensitivity Cognitive Screen may not be sensitive enough to detect the subtle cognitive changes that occur after ADT. In addition, self-report of cognitive function has not been correlated consistently with actual neuropsychological testing (97).

In conclusion, the data show that androgen ablation does have cosequences for cognitive functioning. Larger longitudinal studies are warranted.

\subsection{ADT and changes in body composition}

Male hypogonadism (of any etiology) results in a decline in lean body mass (LBM) and an increase in fat mass, which is reversed with TST replacement (98). A cross-sectional study showed that men undergoing long-term ADT (12-101 months) have increased fat mass in the trunk and all extremities- measured by dual-energy x-ray absorptiometry (DXA), compared with eugonadal men with PCa not undergoing ADT (treated with prostatectomy and/or radiation therapy) and age-matched eugonadal controls (99).

Another case control study examined the prevalence and magnitude of obesity and fat mass in a group of 62 men with PCa receiving ADT for 1-5 yr (100). Healthy men $(n=47)$ with a PSA of less than $4.0 \mathrm{ng} / \mathrm{ml}$ were recruited as controls. The study showed that men with PCa had significantly higher body weight ( $86.5 \mathrm{vs.} 80.6 \mathrm{~kg}$ ) and percent body fat (30 vs. 26\%) than controls.

Meta-analysis of sixteen studies showed that ADT increased percentage of body fat by on average $7.7 \%$ (95\% CI 4.3, 11.2, from seven studies, P < 0.0001) and decreased \% LBM by on average $-2.8 \%(95 \% \mathrm{CI}-3.6,-2.0$, from six studies, $\mathrm{P}<0.0001)$ but for both there was marked heterogeneity between studies (I2 $=99 \%$ I $2=73 \%$, respectively). Similarly, body weight $(2.1 \%, \mathrm{P}<0.0001$ from nine studies) and BMI $(2.2 \%, \mathrm{P}<0.0001$, from eight studies) increased significantly. More extensive changes were seen with longer duration of treatment (101).

These studies prove that ADT results in an unfavorable body composition. The increase of fat mass in patients on ADT correlates positively with rising insulin levels (102). Hence, this increasing adiposity may be the primary event leading to these metabolic complications (possibly via elaboration of adipokines and inflammatory cytokines). Similarly, it is possible that a decrease in muscle mass may result in decreased glucose uptake by the muscle. These changes may ultimately lead to insulin resistance and diabetes in this population, hence 
predisposing them to cardiovascular disease. Lifestyle changes or suitable interventions to minimize the effect of ADT on body composition need to be investigated.

\section{ADT and insulin resistance}

Epidemiological studies have shown that low TST levels predict the development of insulin resistance and type 2 diabetes (103, 104, 105). Studies have also confirmed a direct relationship between serum TST and insulin sensitivity (106). These findings are further supported by interventional studies showing an improvement in insulin sensitivity with TST replacement in hypogonadal obese men (107).

\subsection{Early metabolic changes}

There is some evidence, that the onset of insulin resistance can be detectable after 3 months of ADT $(108,109)$. 3-month prospective study using combined androgen blockade with leuprolide and bicalutamide showed a $43 \%$ increase in fat mass and a $26 \%$ increase in insulin levels from baseline, again indicating development of insulin resistance with increasing adiposity (110). Although there was no significant change in fasting glucose levels, a statistically significant increase in glycosylated hemoglobin was seen (though this increase was within the normal range from 5.46-5.62\%). These observations suggest that insulin resistance develops within a few months of initiating ADT; however, this compensatory hyperinsulinemia prevents the development of diabetes.

\subsection{Late metabolic changes}

Observational study of a population-based cohort found that men undergoing ADT with $\mathrm{GnRH}$ agonists had a higher risk of incident diabetes $(11 \%)$, coronary artery disease (25\%), myocardial infarction, and sudden death (111). Interestingly, orchiectomy was associated only with a higher risk of diabetes. In some men, this risk was evident within 4 months of starting ADT. These findings suggest that although both medical and surgical modalities of ADT result in increased metabolic burden, GnRH analogs are also associated with cardiovascular events.

After 12 months of ADT, serum fasting glucose increased significantly (112), suggesting that men with PCa who are receiving long-term ADT are at risk for developing insulin resistance and hyperglycemia, thus leading to their increased risk of cardiovascular disease (113).

A retrospective study which enrolled 396 patients with a median follow-up of 60.1 months, $36(11.3 \%)$ patients developed new- onset diabetes mellitus (NODM). In 77 patients with pre-existing diabetes, there was an increase of $>/=10 \%$ in serum $\mathrm{HbA} 1 \mathrm{c}$ or fasting glucose levels in $15(19.5 \%)$ and 22 (28.6\%), respectively. On multivariate analysis, a BMI of $>/=30 \mathrm{~kg} / \mathrm{m}(2)$ was associated with an increased risk of developing NODM (odds ratio $4.65, \mathrm{P}=0.031$ ) (114).

In conclusion, patients receiving ADT for PCa with or with no history of diabetes should have routine surveillance of glycaemic control, with appropriate preventive and treatment measures.

\section{ADT and lipid alterations}

Hyperlipidemia is a known risk factor for cardiovascular disease. Recent epidemiological research suggests that low serum TST levels in men are associated with an adverse lipid 
profile, especially elevated total cholesterol, LDL cholesterol, and triglycerides (115). Furthermore, interventional studies have shown that TST replacement in hypogonadal men results in an improvement in lipid profile (116).

During long-term ADT, triglycerides rise by approximately $26 \%$ and total cholesterol approximately $10 \%$. (117, 118, 119) In addition, high-density lipoprotein (HDL) rises approximately $8 \%$ to $11 \%$. The net effect of these changes on cardiovascular risks is unknown. Significant changes can be observed within the first 3 months of treatment, with more modest subsequent change (110).

\section{ADT, metabolic syndrome and cardiovascular disease}

Metabolic syndrome (MS) is a known risk factor for cardiovascular disease (CVD) (120). According to the Adult Treatment Panel III guidelines (121), a man is considered to have MS if he meets 3 of the following 5 criteria: fasting plasma glucose level $>110 \mathrm{mg} / \mathrm{dL}$, serum triglyceride level $150 \mathrm{mg} / \mathrm{dL}$, serum high-density lipoprotein level <40 mg/dL, waist circumference $>102 \mathrm{~cm}$, and blood pressure $\geq 130 / 85 \mathrm{mmHg}$. Subjects on antihypertensive and antilipid medications are also considered positive for the respective criteria. Recently, male hypogonadism has surfaced as an independent risk factor for MS. Cross-sectional studies have shown that men with hypotestosteronemia have a higher prevalence of MS (122). Longitudinal studies also show that lower androgen levels in men independently predict the development of MS (105).

These observations suggest that profound hypogonadism due to ADT imparts increased metabolic burden. Long-term prospective studies are needed to determine the time of onset of various metabolic alterations in these men.

Since MS is associated with CVD, large studies were conducted to assed the CV risk and ADT. A large SEER-Medicare-based analysis of 73,196 men aged 66 years and older with PCa identified significant $\mathrm{GnRH}$ agonist-associated elevations in risk for myocardial infarction $(\mathrm{HR}, 1.11 ; \mathrm{p}=.03)$, sudden cardiac death $(\mathrm{HR}, 1.16 ; \mathrm{p}=.004)$, and new diagnosis of coronary heart disease (HR, 1.16; $\mathrm{p}<$.001) (123). Similarly, a second SEER-Medicare-based study of 23,000 men with PCa found a 20\% ADT-attributable rise in CV morbidity at 1 year (124).

In contrast, a recently reported matched cohort analysis of approximately 20,000 men in an On-tario database found no association between ADT and acute myocardial infarction (HR, $0.91 ; 95 \%$ CI, 0.84-1.00) (125).

A smaller population-based observational study of 3262 men who had undergone prostatectomy for PCa found that ADT was significantly associated with CV mortality, although only in the subset of men aged 65 years and older (126). This analysis failed to validate baseline coronary artery disease and diabetes as risk factors for CV mortality. Finally, combined analysis of 3 randomized trials involving men with localized PCa found that in the subset of men aged 65 years and older, 6 months of treatment with a GnRH agonist led to earlier onset of fatal myocardial infarction (127).

Three large randomized, controlled trials by the Radiation Therapy Oncology Group (RTOG) have been retrospectively analyzed for an association between neoadjuvant/ concomitant/adjuvant ADT and CV mortality. These analyses have not found convincing evidence of an association (128-130). Secondary analyses of a randomized controlled trial from the EORTC found no association between ADT and CV mortality. The RTOG and EORTC trials were randomized, featured large enrollments, and had long-term follow-up. 


\begin{tabular}{|l|l|}
\hline Bone metabolism & $\begin{array}{l}\text { Loss of BMD, skeletal events (fractures), increased } \\
\text { morbidity\&mortality }\end{array}$ \\
\hline Bone marrow & Anaemia \\
\hline Lipid profile alterations & Increased: overall cholesterol, TAG, LDL, HDL \\
\hline Impaired insuline sensitivity & $\begin{array}{l}\text { Hyperinsulinemia, new onset diabetes, worsening existing } \\
\text { DM }\end{array}$ \\
\hline Body composition & $\begin{array}{l}\text { Increase in fat mass, decrease in muscle mass, increased } \\
\text { BMI }\end{array}$ \\
\hline Cardiovascular disease & Increased risk of CV morbidity and mortality (?) \\
\hline Metabolic syndrome & See above \\
\hline Cognitive functions & Impaired spatial cognition, reaction time, other (?) \\
\hline Other & Mood changes, loss of libido \\
\hline
\end{tabular}

Table 2 . Summary of main organ systems affected by severe hypogonadism (by ADT)

\section{References}

[1] Huggins C, Hodges CV. Studies on prostatic cancer. I. The effect of castration, of estrogen and of androgen injection on serum phosphatase in metastatic carcinoma of the prostate. J Urol 2002 Feb;167(2P 2):948-51, discussion 952.

[2] Huggins C, Stevens RE Jr, Hodges CV. Studies on prostate cancer. II. The effect of castration on advanced carcinoma of the prostate gland. Arch Surg 1941;43:209-23.

[3] Shahinian V, Kuo Y, JLFreeman, Goodwin J. Risk of fracture after androgen deprivation for prostate cancer. N Engl J Med 2005; 352:154-164.

[4] Smith MR, Lee H, Nathan DM. Insulin sensitivity during combined androgen blockade for prostate cancer. J Clin Endocrinol Metab. 2006;91(4):1305-8.

[5] Hakimian P, Blute M, Jr, Kashanian J, et al. Metabolic and cardiovascular effects of androgen deprivation therapy. BJU Int. 2008;102:1509-1514

[6] Smith MR, Finkelstein JS, McGovern FJ, et al. Changes in body composition during androgen deprivation therapy for prostate cancer. J Clin Endocrinol Metab. 2002;87:599-603

[7] Saigal CS, Gore JL, Krupski TL, et al. Androgen deprivation therapy increases cardiovascular morbidity in men with prostate cancer. Cancer. 2007;110:1493-1500

[8] Nelson CJ, Lee JS, Gamboa MC, Roth AJ. Cognitive effects of hormone therapy in men with prostate cancer: a review. Cancer. 2008;113(5):1097-106.

[9] Coffey DS (1988) Androgen action and the sex accesory tissues. In: Knobil E, Neill (eds): The physiology of reproduction. J. Raven Press, New York,pp 1081-1119

[10] Baulieu EE (1997) Neurosteroids: of the nervous system, by the nervous system, of the nervous system. In: Rec Prog Horm Res 52: pp 1-32

[11] Saez JM (1994) Leydig cells: endocrine, paracrine and autocrine regulation. Endocr Rev 16: $574-626$

[12] Rommerts FFG (2004), Testosterone: Action, Deficiency, Subsitution. Third Edition In:Nieschlag E, Behre HM (Eds): Testosterone: an overview of biosynthesis, transport, metabolism and non genomic functions. Cambrigde University Press, pp 1-39

[13] Wilson JD, Griffin JE, Russel DW (1993) Steroid 5a-reductuase 2 deficiency. Endocr. Rev. 14:577-593 
[14] Tindall DJ, Rittmaster RS (2008) : The rationale for inhibiting 5alpha-reductase isoenzymes in the prevention and treatment of prostate cancer. J Urol. 2008 Apr;179(4):1235-42.

[15] Baskin LS (2004) Abnormalities of sexual determination \&differentation In:Tanagho EA, McAninch WJ (Eds) Smith's general urology, 16th Edition, Lange Medical Books, p660 (2004)

[16] Uemura M, Tamura K, Chung S, Honma S, Okuyama A, Nakamura Y, Nakagawa H. (2008): Novel 5 alpha-steroid reductase (SRD5A3, type-3) is overexpressed in hormone-refractory prostate cancer., Cancer Sci. 2008 Jan;99(1):81-6.

[17] Ziaran S, Goncalves FM, Štefančík J, Breza J Sn. The effect of androgens on cognitive function and bone. Lek Obzor. 2009; 3:116-20

[18] Guo Z, Benten WP, Krucken J, Wunderlich F (2002), Nogenomic testosterone calcium signaling. Genotropic actions in androgen receptor-free macrophages J Biol Chem 277:29600-29607

[19] Castoria G, Lombardi M, Barone MV, Bilancio A, Di Domenico M, Bottero D, Vitale F, Migliaccio A, Auricchio F.: Androgen-stimulated DNA synthesis and cytoskeletal changes in fibroblasts by a nontranscriptional receptor action., J Cell Biol. 2003 May 12;161(3):547-56.

[20] Papakonstanti E.A, Kampa M, Castanas E, and Stournaras C. A rapid, nongenomic, signaling pathway regulates the actin reorganization and PSA secretion induced by membrane testosterone receptors' activation. Mol. Endocrinol. 17(5), 870-881 (2003).

[21] Klocker H, Gromoll J, Cato ACB, (2004) The androgen receptor: molecular biology, Third Edition In:Nieschlag E, Behre HM (Eds) Testosterone: Action, Deficiency, Subsitution. Cambrigde University Press,pp 39-92

[22] Lee DK, Duan HO, Chang C.: From androgen receptor to the general transcription factor TFIIH. Identification of cdk activating kinase (CAK) as an androgen receptor $\mathrm{NH}(2)$-terminal associated coactivator.,: J Biol Chem. 2000 Mar 31;275(13):9308-13

[23] Quingley CA, DeBellis A, Marschke KB, El-Awady MK, Wilson EM, French FS (1995). Androgen receptor defects: historical, clinical and molecular perspectives., Endocr Rev 16:271-321

[24] Colvard DS., Erikse EF., Keeting PE., Wilson EM., Lubahn DB., French FS., Riggs BL., Spelsberg TC., (1989) Identification of androgen receptors in normal human osteobast-like cells. Proc Natl Acad Sci USA 86: 854-857

[25] Kasperk CH., Wakley GK., Hierl T., Ziegler R., (1997) Gonadal and adrenal androgens are potent regulators of human bone cell metabolism in vitro. J Bone Miner Res 12: $464-471$

[26] Liegibel UM., Sommer U., Tomakidi P., Hilscher U., Van den Heuvel L., Pirzer R., Hillmeier J., Nawroth P., Kasperk C., (2002) Concerted action of androgens and mechanical strain shifts bone metabolism from high turnover into an osteoanabolic mode. J Exp Med 196: 1387- 1392

[27] Khosla S., (2001) Minireview: the OPG/RANKL/RANK system. Endocrinology 142: 5050-5055

[28] Szulz P., Hofbauer LC., Heufelder AE., Roth S., Delmas PD., (2001) Osteoprotegerin serum levels in men: correlation with age, estrogen, and testosterone status. J Clin Endocrinol Metab 86: 3162- 3165 
[29] Chen Q, Kaji H, Sugimoto T, Chihara K (2001). Testosterone inhibits osteoclast formation formation stimulated by parathyroid hormone through androgen receptor. FEBS Lett 491:91-93

[30] Zitzmann M, Nieschlag E (2004), Androgens and bone metabolism. In: Nieschlag E, Behre HM (Eds): Testosterone: Action, Deficiency, Subsitution. Third Edition Cambrigde University Press, pp 233-254

[31] Riggs BL., Khosla S., Melton JR., 3 rd (2002) Sex steroid and the construction and conservation of the adult skeleton. Endocr Rev 23: 279-302

[32] Eriksen EF, Colvard DS, Berg NJ, Graham ML, Mann KG, Spelsberg TC, Riggs BL (1988). Evidence of estrogen receptors in normal human osteoblast-like cells. Science 241:84-86

[33] Ourlsler MJ, Pederson L, Fitzpatrick L, Riggs BL (1994). Human giant cell tumors of the bone (osteoclastomas) are estrogen target cells. Proc Natl Acad Sci USA 96:505-510

[34] Braidman I, Baris C, Wood L, Selby P, Adams J, Feemont A, Hoyland J (2000). Preliminary evidence for impaired estrogen receptor protein expression in ostetoblast and osteocytes from men with idiopatic osteoporosis. Bone 26:423-427

[35] Grumbach MM (2000) Estrogen, bone, growth and sex: a sea change in conventional wisdom. J Pediatr Endocrinol Metab 13:1439-1455

[36] Walsh PC. Physiologic basis for hormonal therapy in carcinoma of the prostate. Urol Clin North Am 1975 Feb;2(1):125-40

[37] Bangma CH, Roemeling S, Schröder FH. Overdiagnosis and overtreatment of early detected prostate cancer.World J Urol. 2007 Mar;25(1):3-9.

[38] WHO Assessment od fracture risk and its application to screening for postmenopausal osteoporosis. WHO Technical report series. Geneva, WHO, 1994.

[39] Kanis JA, Melton LJ, Christiansen C, Johnston CC, Khaltaev N. The diagnosis of osteoporosis. J Bone Miner Res 1994; 9: 1137-1141.

[40] Looker AC, Orwoll ES, Johnston Jr CC, Lindsay RL, Wahner HW, Dunn WL, Calvo MS, Harris TB, Heyse SP. Prevalence of low femoral bone density in older US adults from NHANES III. J Bone Miner Res 1997; 12: 1761-1768.

[41] Bilezikian JP. Osteoporosis in men. J Clin Endocrinol Metab 1999; 84: 3431-3434.

[42] Kiebzak GM, Beinart GA, Perser K, Ambrose CG, Siff SJ, Heggeness MH. Undertreatment of osteoporosis in men with hip fracture. Arch Intern Med 2002; 162: 2217-2222

[43] Krane SM, Holik MF. Metabolic bone disease. In: Fauci AS, Braunwald E, Isselbacher KJ, et al., editors. Harrison's principles of internal medicine. 14th edition. Volume 2. New York: McGraw-Hill, 1998:2247-2253.

[44] Orwoll ES, Klein RF. Osteoporosis in men. Endocrine Reviews 1995; 16: 87-116.

[45] Seeman E. Pathogenesis of bone fragility in women and men. Lancet 2002; 359: 18411850.

[46] Smith MR. Diagnosis and management of treatment-related osteoporosis in men with prostate carcinoma. Cancer 2003; 97: 789-795.

[47] Hannan MT, Felson DT, Dawson-Hughes B, Tucker KL, Cupples LA, Wilson PWF, Kiel DP. Risk factors for longitudinal bone loss in elderly men and women: the Framingham osteoporosis study. J Bone Miner Res 2000; 15: 710-720. 
[48] Jones G, Nguyen T, Sambrook P, Kelly PJ, Eisman JA. Progressive loss of bone in the femoral neck in elderly people: longitudinal findings from the Dubbo osteoporosis epidemiology study. BMJ 1994; 309: 691-695.

[49] Melton LJ, Chrischilles EA, Cooper C, Lane AW, Riggs BL. How many women have osteoporosis. J Bone Miner Res 1992; 7: 1005-1010.

[50] Forsen L, Sogaard AJ, Meyer HE, Edna T, Kopjar B. Survival after hip fracture: shortand long-term excess mortality according to age and gender. Osteoporos Int 1999; 10: 73-78.

[51] Center JR, Nguyen TV, Schneider D, Sambrook PN, Eisman JA. Mortality after all major types of osteoporotic fracture in men and women: an observational study. Lancet 1999; 353: 878-882.

[52] Abrahamsen B, van Staa T, Ariely R, Olson M, Cooper C. Excess mortality following hip fracture: a systematic epidemiological review. Osteoporos Int 2009; 20(10): 16331650.

[53] Diamond T, Higano C, Smith M, Guise T, Singer F. Osteoporosis in men with prostate cancinoma receiving androgen deprivation therapy: recommendatios for diagnosis and therapies. Cancer 2004; 100: 892-899.

[54] WHO: Assessment of fracture risk and its application to screening for postmenopausal osteoporosis repot of WHO Study Group. Geneva, 1994: World Health Organization

[55] Kanis J, Seeman E, Johnell O, Rizzoli R, Delmas P. The perspective of the International Osteoporosis Foundation on the official positions of the International Society for Clinical Densitometry. Osteoporosis Int 2005; 16: 456-459.

[56] http://www.uroweb.org/guidelines/online-guidelines/

[57] Daniell HW, Dunn SR, Fergusson DW, Lomas G, Niazi Z, Srtatte PT. Progressive osteoporosis during andorgen deprivation therapy for prostate cancer. J Urol 2000; 163: $181-186$.

[58] Greenspan SL, Coates P, Sereika SM, Nelson JB, Trump DL, Resnick NM. Bone loss after initiation of androgen deprivation therapy in patients with prostate cancer. J Clin Endocrinol Metab 2005; 12: 6410-6417.

[59] Ahlborg HG, Nguyen ND, Center JR, Eisman JA, Nguyen TV. Incidence and risk factors for low trauma fractures in men with prostate cancer. Bone 2008; 43: 556-660.

[60] Oefelein MG, Ricchiuti V, Conrad W, Resnick MI. Skeletal fractures negatively correlate with overall survival in men with prostate cancer. J Urol 2002; 168 (3): 1005-1007.

[61] Inoue T, Segawa T, Kamba T, Yoshimura K, Nakamura E, Nishiyama H, Ito N, Kamoto T, Habuchi T, Ogawa O. Prevalence of skeletal complications and their impact on survival of hormone refractory prostate cancer patients in Japan. Urology 2009; 73 (5): 1104-1109.

[62] Saad F, Olsson C, Schulman CC. Skeletal morbidity in men with prostate cancer: quality-of-life considerations throughout the continuum of care. Eur Urol 2004; 46 (6): 731-739.

[63] McKiernan JM, Delea TE, Liss M. et al. Impact of skeletal complications on total medical care costs in prostate cancer patients with bone metastases. Proc Am Soc Clin Oncol 2004; 23: 531 (abstract no. 6057) 
[64] Bubendorf L, Schopfer A, Wagner U, Sauter G, Moch H, Willi N, Gasser TC, Mihatsch MJ. Metastatic patterns of prostate cancer: an autopsy study of 1,589 patients. Hum Pathol 2000; 31:578-583.

[65] Liotta LA, Kohn E. Cancer invasion and metastases. JAMA 1990; 263: 1123-6

[66] Garnero P, Buchs N, Zekri J, Rizzoli R, Coleman RE, Delmas PD. Markers of bone turnover for the management of patients with bone metastases from prostate cancer. Br J Cancer 2000; 82: 858-64

[67] Saad F., Gleason DM., Murray R. Long-term efficacy of zoledronic acid for the prevention of skeletal complications in patients with metastatic hormone-refractory prostate cancer. J Natl Cancer Inst 2004; 96: 879-82

[68] McKiernan JM, Delea TE, Liss M. et al. Impact of skeletal complications on total medical care costs in prostate cancer patients with bone metastases. Proc Am Soc Clin Oncol 2004; 23: 531

[69] Ziaran S, Goncalves FM, Wendl J, Trebaticky B, Breza J Sn. Evaluation of bone mass density on patients with prostate cancer prior to the start of androgen deprivation therapy. Bratisl Med J 2009; 110(9):559-562.

[70] Ziaran S, Goncalves FM, Breza J Sn. Hormone naive patients with advanced prostate cancer have lower baseline bone mass density than healthy control. Bratisl Med J 2011; 131 (article in press)

[71] Farhat GN, Taioli E, Cauley JA, Zmuda JM, Orwoll E, Bauer DC, Wilt TJ, Hoffman AR, Beer TM, Shikany JM, Daniels N, Chan J, Fink HA, Barrett-Connor E, Parsons JK, Bunker CH. Osteoporotic Fractures in Men (MrOS) Study Group. The association of bone mineral density with prostate cancer risk in the Osteoporotic Fractures in Men (MrOS) Study. Cancer Epidemiol Biomarkers Prev 2009; 18: 148-154.

[72] Murphy et al. Management of Postmenopausal Osteoporosis. JAOA 2003; 103: 6-11

[73] Smith MR, McGovern FJ, Zietman AL, Fallon MA, Hayden DL et al. Pamidronate to prevent bone loss during androgen-deprivation therapy for prostate cancer. $\mathrm{N}$ Engl J Med 2001; 13:948-955.

[74] Ishizaka K, Machida T, Kobayashi S, Kanbe N, Kitahara S et al. Preventive effect of risedronate on bone loss in men receiving androgen-deprivation therapy for prostate cancer. Int J Urol 2007; 12:1071-1075.

[75] Planas J, Trilla E, Raventós C, Cecchini L, Orsola A, Salvador C, Placer J, Encabo G, Morote J. Alendronate decreases the fracture risk in patients with prostate cancer on androgen-deprivation therapy and with severe osteopenia or osteoporosis. BJU Int. 2009;104(11):1637-40.

[76] Smith MR, Eastham J, Gleason DM, et al. Randomized controlled trial of zoledronic acid to prevent bone loss in men receiving androgen deprivation therapy for nonmetastatic prostate cancer. J Urol 2003;169(6):2008-12.

[77] Michaelson MD, Kaufman DS, Lee H, et al. Randomized controlled trial of annual zoledronic acid to prevent gonadotropin-releasing hormone agonist-induced bone loss in men with prostate cancer. J Clin Oncol 2007;25(9):1038-42.

[78] Satoh T, Kimura M, Matsumoto K, Tabata K, Okusa H, Bessho H, Iwamura M, Ishiyama $\mathrm{H}$, Hayakawa K, Baba S. Single infusion of zoledronic acid to prevent androgen deprivation therapy-induced bone loss in men with hormone-naive prostate carcinoma. Cancer. 2009;115(15):3468-74. 
[79] Migliorati CA, Siegel MA, Elting LS. Bisphosphonate-associated osteonecrosis: a longterm complication of bisphosphonate treatment. Lancet Oncol 2006;7(6):508-1

[80] Wadhwa VK, Weston R, Parr NJ. Frequency of zoledronic acid to prevent further bone loss in osteoporotic patients undergoing androgen deprivation therapy for prostate cancer. BJU Int 2009, 13. [Epub ahead of print]

[81] Smith MR, Egerdie B, Hernández Toriz N, et al; Denosumab HALT Prostate Cancer Study Group. Denosumab in men receiving androgen-deprivation therapy for prostate cancer. N Engl J Med 2009;361(8):745-55.

[82] Halpern DF (2000), Sex differences in cognitive abilities (3rd Ed) Lawrence Erlbaum, Hillsdale (NJ)

[83] Collaer ML, Hines M (1995) Human behavioral sex differences: A role for gonadal hormones during early development? Psycholl Bull 118:55-107

[84] O'Connor DB, Archer J, Hair WM, Wu FCW (2001) Activational effects of TST on cognitive function in men. Neuropsychologia 39:1385-1394

[85] Simonson E, Kearnes Wm, Enzer N (1941) Effect of oral administration of methyltestosterone on fatigue in eunuchoids and castrates. Endocrinilogy 28:506512

[86] Duker H (1957) Leistungfahigkeit und Keimdrusenhormone. Barth, Munchen

[87] Slabbekoorn D, van Goozen SHM, Megens J, Gooren LJG (1999) Activating effects of cross-sex hormones on cognitive functioning: A study of short term and long term hormone effects in transsexuals. Psychoneuroendocrinology 24:423-447

[88] Klaiber EL, Broverman DM, Vogel W, Abraham GE, Cone FL (1971) Effects of infused TST on mental performances and serum LH. J Clin Endrocrinol Metab 32:341-349

[89] Cherrier MMM. Androgens and cognitive function. J Endocrinologic Invest. 2005; 28 ( 3 suppl ): 65-75.

[90] Yaffe K. Testosterone and the brain: uncharted territory [letter]. Lancet Neurol. 2004; 3: 270.

[91] Yaffe K,Grady D,Pressman A,Cummings S. Serum estrogen levels, cognitive performance, and risk of cognitive decline in older community women. J Am Geriatr Soc. 1998; 46: 816-821.

[92] Wefel JS,Kayl AE,Meyers CA. Neuropsychological dysfunction associated with cancer and cancer therapies: a conceptual review of an emerging target. Br J Cancer. 2004; 90: 1691-1696.

[93] Yaffe K,Lui LY,Zmuda J,Cauley J. Sex hormones and cognitive function in older men. J Am Geriatr Soc. 2002; 50: 707-712.

[94] Green HJ,Pakenham KI,Headley BC, et al. Altered cognitive function in men treated for prostate cancer with luteinizing hormone-releasing hormone analogues and cyproterone acetate: a randomized controlled trial. BJU Int. 2002; 90: 427-432

[95] Salminen EK,Portin RI,Koskinen A,Helenius H,Nurmi M. Associations between serum testosterone fall and cognitive function in prostate cancer patients. Clin Care Res. 2004; 10: 7575-7582.

[96] Jenkins VA,Bloomfield DJ,Shilling VM,Edginton TL. Does neoadjuvant hormone therapy for early prostate cancer affect cognition? Results from a pilot study. BJU Int. 2005; 96: 48-53. 
[97] Joly F,Alibhai SM,Galica J, et al. Impact of androgen deprivation therapy on physical and cognitive function, as well as quality of life of patients with nonmetastatic prostate cancer. J Urol. 2006; 176 (6 pt 1): 2443-2447

[98] Basaria S, Wahlstrom JT, Dobs AS 2001 Anabolic-androgenic steroid therapy in the treatment of chronic diseases. J Clin Endocrinol Metab 86:5108-5117

[99] Basaria S, Lieb 2nd J, Tang A, DeWeese T, Carducci M, Eisenberger M, Dobs AS 2002 Long-term effects of androgen deprivation therapy in prostate cancer patients. Clin Endocrinol (Oxf) 56:779-786

[100] Chen Z, Maricic M, Nguyen P, Ahmann FR, Bruhn R, Dalkin BL 2002 Low bone density and high percentage of body fat among men who were treated with androgen deprivation therapy for prostate carcinoma. Cancer 95:2136-2144

[101] Haseen F, Murray LJ, Cardwell CR, O'Sullivan JM, Cantwell MM. The effect of androgen deprivation therapy on body composition in men with prostate cancer: systematic review and meta-analysis. J Cancer Surviv. 2010;4(2):128-39

[102] Smith JC, Bennett S, Evans LM, Kynaston HG, Parmar M, Mason MD, Cockcroft JR, Scanlon MF, Davies JS2001 The effects of induced hypogonadism on arterial stiffness, body composition, and metabolic parameters in males with prostate cancer. J Clin Endocrinol Metab

[103] Haffner SM, Shaten J, Stern MP, Smith GD, Kuller L 1996 Low levels of sex hormonebinding globulin and testosterone predict the development of non-insulindependent diabetes mellitus in men. MRFIT Research Group. Multiple Risk Factor Intervention Trial. Am J Epidemiol 143:889-897

[104] Haffner SM, Valdez RA, Mykkanen L, Stern MP, Katz MS 1994 Decreased testosterone and dehydroepiandrosterone sulfate concentrations are associated with increased insulin and glucose concentrations in nondiabetic men. Metabolism 43:599-603

[105] Laaksonen DE, Niskanen L, Punnonen K, Nyyssönen K, Tuomainen TP, Valkonen VP, Salonen R, Salonen JT2004 Testosterone and sex hormone-binding globulin predict the metabolic syndrome and diabetes in middle-aged men. Diabetes Care 27:10361041

[106] Pitteloud N, Hardin M, Dwyer AA, Valassi E, Yialamas M, Elahi D, Hayes FJ 2005 Increasing insulin resistance is associated with a decrease in Leydig cell testosterone secretion in men. J Clin Endocrinol Metab 90:2636-2641

[107] Marin P, Holmang S, Jonsson L, Sjöström L, Kvist H, Holm G, Lindstedt G, Björntorp P 1992 The effects of testosterone treatment on body composition and metabolism in middle-aged obese men. Int J Obes Relat Metab Disord 16:991-997

[108] Smith JC, Bennett S, Evans LM, Kynaston HG, Parmar M, Mason MD, Cockcroft JR, Scanlon MF, Davies JS2001 The effects of induced hypogonadism on arterial stiffness, body composition, and metabolic parameters in males with prostate cancer. J Clin Endocrinol Metab 86:4261-4267

[109] Dockery F, Bulpitt CJ, Agarwal S, Donaldson M, Rajkumar C 2003 Testosterone suppression in men with prostate cancer leads to an increase in arterial stiffness and hyperinsulinaemia. Clin Sci (Lond) 104:195-201

[110] Smith MR, Lee H, Nathan DM 2006 Insulin sensitivity during combined androgen blockade for prostate cancer. J Clin Endocrinol Metab 91:1305-1308

[111] Keating NL, O'Malley AJ, Smith MR 2006 Diabetes and cardiovascular disease during androgen deprivation therapy for prostate cancer. J Clin Oncol 24:4448-4456 
[112] Mohamedali HZ, Breunis H, Timilshina N, Alibhai SM. Changes in blood glucose and cholesterol levels due to androgen deprivation therapy in men with non-metastatic prostate cancer. Can Urol Assoc J. 201;5(1):28-32.

[113] Basaria S, Muller DC, Carducci MA, Egan J, Dobs AS. Hyperglycemia and insulin resistance in men with prostate carcinoma who receive androgen-deprivation therapy. Cancer. 2006;106(3):581-8.

[114] Derweesh IH, Diblasio CJ, Kincade MC, Malcolm JB, Lamar KD, Patterson AL, Kitabchi AE, Wake RW. Risk of new-onset diabetes mellitus and worsening glycaemic variables for established diabetes in men undergoing androgendeprivation therapy for prostate cancer. BJU Int. 2007;100(5):1060-5.

[115] Haffner SM, Mykkanen L, Valdez RA, Katz MS 1993 Relationship of sex hormones to lipids and lipoproteins in nondiabetic men. J Clin Endocrinol Metab 77:1610-1615

[116] Malkin CJ, Pugh PJ, Jones RD, Kapoor D, Channer KS, Jones TH 2004 The effect of testosterone replacement on endogenous inflammatory cytokines and lipid profiles in hypogonadal men. J Clin Endocrinol Metab 89:3313-3318

[117] Smith MR, Finkelstein JS, McGovern FJ, et al. Changes in body composition during androgen deprivation therapy for prostate cancer. J Clin Endocrinol Metab. 2002;87:599-603.

[118] Dockery F, Bulpitt CJ, Agarwal S, et al. Testosterone suppression in men with prostate cancer leads to an increase in arterial stiffness and hyperinsulinaemia. Clin Sci (Lond) 2003;104:195-201

[119] Eri LM, Urdal P, Bechensteen AG. Effects of the luteinizing hormone-releasing hormone agonist leuprolide on lipoproteins, fibrinogen and plasminogen activator inhibitor in patients with benign prostatic hyperplasia. J Urol. 1995;154:100-104

[120] Eckel RH, Grundy SM, Zimmet PZ. The metabolic syndrome. Lancet. 2005;365: 1415 1428

[121] Expert Panel on Detection, Evaluation and Treatment of High Blood Cholesterol in Adults. Executive summary of the third report of the National Cholesterol Education Program (NCEP) Expert Panel on Detection, Evaluation, and Treatment of High Blood Cholesterol in Adults (Adult Treatment Panel III). JAMA. 2001;285: $2486-2497$

[122] Muller M, Grobbee DE, den Tonkelaar I, Lamberts SW, van der Schouw YT. Endogenous sex hormones and metabolic syndrome in aging men. J Clin Endocrinol Metab. 2005; 90: 2618 -2623

[123] Keating NL, O'Malley AJ, Smith MR. Diabetes and cardiovascular disease during androgen deprivation therapy for prostate cancer. J Clin Oncol. 2006;24:4448-4456.

[124] Saigal CS, Gore JL, Krupski TL, et al. Androgen deprivation therapy increases cardiovascular morbidity in men with prostate cancer. Cancer. 2007;110:1493-1500.

[125] Alibhai SM, Duong-Hua M, Sutradhar R, et al. Impact of androgen deprivation therapy on cardiovascular disease and diabetes. J Clin Oncol. 2009;27:3452-3458

[126] Tsai HK, D'Amico AV, Sadetsky N, et al. Androgen deprivation therapy for localized prostate cancer and the risk of cardiovascular mortality. J Natl Cancer Inst. 2007;99:1516-1524

[127] D'Amico AV, Denham JW, Crook J, et al. Influence of androgen suppression therapy for prostate cancer on the frequency and timing of fatal myocardial infarctions. J Clin Oncol. 2007;25:2420-2425 
[128] Efstathiou JA, Bae K, Shipley WU, et al. Cardiovascular mortality and duration of androgen deprivation for locally advanced prostate cancer: analysis of RTOG 92-02. Eur Urol. 2008;54:816-823.

[129] Roach M, III, Bae K, Speight J, et al. Short-term neoadjuvant androgen deprivation therapy and external-beam radiotherapy for locally advanced prostate cancer: longterm results of RTOG 8610. J Clin Oncol. 2008;26:585-591

[130] Efstathiou JA, Bae K, Shipley WU, et al. Cardiovascular mortality after androgen deprivation therapy for locally advanced prostate cancer: RTOG 85-31. J Clin Oncol. 2009;27:92-99 


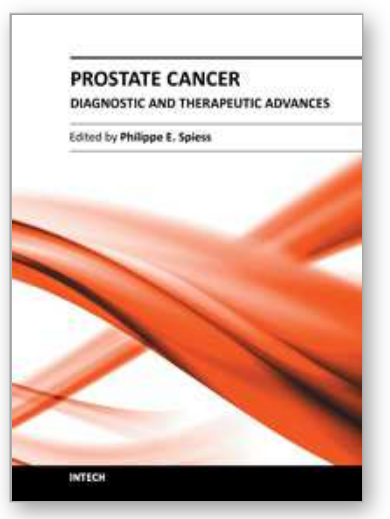

\author{
Prostate Cancer - Diagnostic and Therapeutic Advances \\ Edited by Dr. Philippe E. Spiess
}

ISBN 978-953-307-319-4

Hard cover, 378 pages

Publisher InTech

Published online 25, November, 2011

Published in print edition November, 2011

In this book entitled "Prostate Cancer - Diagnostic and Therapeutic Advances", we highlight many of the significant advances made in our treatment armamentarium of prostate cancer. The book is subdivided into four sections termed: 1) novel diagnostic approaches, 2) surgical treatments options, 3) radiation therapy and its potential sequelae, and 4) medical management and its treatment complications. After reading the present book, readers will be very familiar with the major clinical advances made in our multifaceted treatment approach to prostate cancer over the past decade. This book is a tribute to our pioneering urologists and allied healthcare professionals who have continually pushed forward our traditional therapeutic envelope.

\title{
How to reference
}

In order to correctly reference this scholarly work, feel free to copy and paste the following:

Stanislav Ziaran (2011). Androgen Deprivation Therapy for Prostate Cancer, Prostate Cancer - Diagnostic and Therapeutic Advances, Dr. Philippe E. Spiess (Ed.), ISBN: 978-953-307-319-4, InTech, Available from: http://www.intechopen.com/books/prostate-cancer-diagnostic-and-therapeutic-advances/androgendeprivation-therapy-for-prostate-cancer

\section{INTECH}

open science | open minds

\section{InTech Europe}

University Campus STeP Ri Slavka Krautzeka 83/A 51000 Rijeka, Croatia Phone: +385 (51) 770447

Fax: +385 (51) 686166 www.intechopen.com

\section{InTech China}

Unit 405, Office Block, Hotel Equatorial Shanghai No.65, Yan An Road (West), Shanghai, 200040, China 中国上海市延安西路65号上海国际贵都大饭店办公楼 405 单元 Phone: +86-21-62489820

Fax: $+86-21-62489821$ 
(C) 2011 The Author(s). Licensee IntechOpen. This is an open access article distributed under the terms of the Creative Commons Attribution 3.0 License, which permits unrestricted use, distribution, and reproduction in any medium, provided the original work is properly cited. 